УДК 81’25’38:659.131.2

DOI https://doi.org/10.26661/2414-1135-2021-83-38

\title{
РОБОТА НАД ПЕРЕКЛАДОМ РЕКЛАМНИХ ТЕКСТІВ
}

\author{
Черняк О. П. \\ кандидат філологічних наук, доцент, \\ завідувач кафедри іноземних мов та перекладу \\ Волинський національний університет імені Лесі Украӥнки \\ пр. Волі, 13, Луиььк, Україна \\ orcid.org/0000-0002-3848-0690 \\ Chernyak.Oksana@vnu.edu.ua \\ Петровська Н. М. \\ кандидат філологічних наук, дочент, \\ доиент кафедри іноземних мов та перекладу \\ Волинський наџіональний університет імені Лесі Украӥнки \\ пр. Волі, 13, Луиьк, Україна \\ orcid.org/0000-0002-8028-1847 \\ Petrovska.Nadija@vnu.edu.ua
}

\begin{abstract}
Ключові слова: перекладацькі трансформації, калькування, наближений переклад, дослівний переклад, художні засоби.
\end{abstract}

У статті виокремлено й проаналізовано особливості рекламного тексту, який розглядається як коротке інформаційне повідомлення, створене для того, щоб стимулювати збут продукту або послуги. Це повідомлення, яке має сильний переконливий вплив, виражений за допомогою лінгвістичних засобів мови. Рекламні тексти часто націлені на велику аудиторію й розраховані на переконання цієї аудиторії придбати певний продукт. Тому основне завдання перекладача - збереження цієї мети, що вимагає врахування певних особливостей і функцій у процесі перекладу. Досліджено структуру рекламного тексту й виділено основні його частини. Виявлено, що переклад рекламного тексту залежить від сфери спілкування, які можна представити такими блоками, як торговельнокомерційна, соціально-культурна, навчально-професійна, сімейнопобутова та спортивно-оздоровча.

Уніфіковано завдання на переклад реклами й розглянуто етапи роботи 3 рекламним текстом. Виявлено закономірності та специфіку відбору мовних засобів для надання тексту реклами виразності, лаконічної інформативності, привабливості й переконливості з метою максимального впливу на потенційного споживача. Установлено, що при перекладі реклам зазвичай використовують два основні методи: калькування й різного роду перекладацькі трансформації. Визначено види перекладу, які використовуються при перекладі рекламних текстів. Виявлено, що за своєю складністю переклад рекламного тексту схожий на переклад художнього твору. Проаналізовано художні засоби, які використовують при перекладі реклами. Установлено, що алегорія, метафора, порівняння, паралелізм, різні види повторів, алітерація, ономатопея, концентрація імперативних форм дієслова й конотативних прикметників - усе це широко презентовано в рекламних текстах. Виявлено, що загальними рисами всіх рекламних текстів можна вважати специфічний підбір лексики, низькочастотних слів; часто стилістично забарвлені слова; уживання ідіом і цитат для створення образності; заклик до дій за допомогою імперативу; широке використання особових і присвійних займенників; використання номінативних речень; прийом паралелізму й повтору; широкий спектр прикметників і прислівників. 


\title{
WORK ON ADVERTISING TEXTS TRANSLATION
}

\author{
Cherniak O. P. \\ Candidate of Philological Sciences, Associate Professor, \\ Head of the Department of Foreign Languages and Translation \\ Lesia Ukrainka Volyn National University \\ Voli av., 13, Lutsk, Ukraine \\ orcid.org/0000-0002-3848-0690 \\ Chernyak.Oksana@vnu.edu.ua \\ Petrovska N. M. \\ Candidate of Philological Sciences, Associate Professor, \\ Associate Professor at the Department of Foreign Languages and Translation \\ Lesia Ukrainka Volyn National University \\ Voli av., 13, Lutsk, Ukraine \\ orcid.org/0000-0002-8028-1847 \\ Petrovska.Nadija@vnu.edu.ua
}

Key words: translation transformations, loan translation, loose translation, word-for-word translation, figures of speech.
The article highlights and analyzes the features of advertising text, which is considered as a short information message created to stimulate sales of a product or service. This is a message that has a strong persuasive effect, expressed through the linguistic means of speech. Advertising texts are often aimed at a large audience and are designed to persuade that audience to buy a particular product. Therefore, the main task of the translator is to preserve this goal, which requires taking into account certain features and functions in the translation process. The article examines the structure of advertising text and highlights its main parts. It was found that the translation of the advertising text depends on the sphere of communication, which can be represented by the following blocks: trade and commercial, socio-cultural, educational and professional, family and household, sports and health

The tasks for advertising translation are unified and the stages of work with advertising text are considered. Regularities and specifics of selection of language means for giving the text of advertising expressiveness, laconic informativeness, attractiveness and persuasiveness for the purpose of the maximum influence on the potential consumer are revealed. It is established that when translating advertisements, two main methods are usually used: loan translation and various kinds of translation transformations. The types of translation used in the translation of advertising texts are defined. It was found that the translation of the advertising text is similar in its complexity to the translation of a fiction. The figures of speech used in the translation of advertising are analyzed. It is established that allegory, metaphor, comparison, parallelism, different types of repetitions, alliteration, onomatopoeia, concentration of imperative verb forms and connotative adjectives are widely presented in advertising texts. It is revealed that the general features of all advertising texts are the following: specific selection of vocabulary, low-frequency words; often stylistically colored words; use of idioms and quotations to create imagery; a call to action through the imperative; extensive use of personal and possessive pronouns; use of nominative sentences; reception of parallelism and repetition; a wide range of adjectives and adverbs. 
Постановка проблеми. Реклама відіграє важливу роль у нашому повсякденному житті. Вона визначає імідж і спосіб життя, впливає на наше мислення, а також на ставлення до себе й навколишнього світу. Кожна людина, навіть не усвідомлюючи цього, знаходиться під впливом реклами. Сьогодні успішне ведення підприємницької діяльності неможливе без використання реклами. При правильній організації реклама є високоефективним засобом розвитку підприємницької діяльності, який сприяє досягненню поставлених стратегічних і тактичних цілей.

$\mathrm{У}$ наш час дедалі очевиднішим $\epsilon$ факт, що людство розвивається через розширення взаємозв'язку, взаємозалежності й взаєморозуміння різних країн, народів, культур. Однією з форм існування соціально-мовного середовища та засобом відображення іноземної дійсності є тексти засобів масової комунікації, зокрема рекламні тексти (далі - РТ).

Актуальність дослідження зумовлена необхідністю виявлення в рекламному тексті мовленнєвих і мовних засобів, поглиблення аналізу мовних одиниць із позиції їх ролі в досягненні мети рекламної комунікації. Питання про можливість ефективного використання міжкультурної реклами набуває особливої актуальності у зв'язку 3 процесом глобалізації мовних і культурних контактів.

Метою дослідження $\epsilon$ виявлення закономірностей і специфіки відбору мовних засобів для надання тексту реклами виразності, лаконічної інформативності, привабливості й переконливості 3 метою максимального впливу на потенційного споживача.

Досягнення мети передбачає розв'язання таких завдань: дослідити структуру рекламного тексту та виділити основні його частини; розглянути етапи роботи 3 рекламним текстом; визначити види перекладу рекламних текстів; проаналізувати художні засоби, які використовують при перекладі реклами.

Об'єкт дослідження становлять рекламні тексти.

Предмет дослідження - особливості перекладу рекламних текстів, ураховуючи їх структуру та сферу використання.

Аналіз останніх досліджень і публікацій. Реклама неодноразово була об'єктом лінгвістичного дослідження. Наукові праці багатьох лінгвістів присвячено вивченню структурних, семантичних, жанрових, стилістичних і комунікативних особливостей рекламної мови й тексту [1-7]. Т. Добросклонська в роботі, присвяченій вивченню медіалінгвістики, акцентує увагу на таких властивостях рекламних текстів: «Рекламні тексти найбільш повно поєднують у собі реа- лізацію двох функцій впливу: функцію впливу мови, яка реалізується за допомогою усього арсеналу лінгвістичних засобів виразності, і функцію впливу засобів масової комунікації, яка реалізується шляхом застосування особливих медіа технологій» $[8$, с. 135]. Значну увагу вивченню проблеми перекладу рекламних текстів приділяли також зарубіжні лінгвісти [9-12]. Поняття «рекламний текст» - це не лише словесне оформлення певної ідеї, він містить у собі сукупність екстралінгвістичних компонентів: графіків, образів, звуків, конкретний набір яких залежить від носія засобів масової інформації. Таке тлумачення поняття «рекламний текст» знаходить своє відбиття в роботах багатьох англомовних дослідників, зокрема в книзі Анжели Годдар "The Language of Advertising", яка пише: "Тут слово “текст" (стосовно до реклами) використовується в його найширшому значенні, включаючи як візуальні зображення, так і вербальну мову» $[9$, с. 6$]$.

Виклад основного матеріалу дослідження. Ми розглядаємо РТ як коротке інформаційне повідомлення, створене для того, щоб стимулювати збут продукту або послуги. Це повідомлення, яке має сильний переконливий вплив, виражений за допомогою лінгвістичних засобів мови. Рекламні тексти часто націлені на велику аудиторію й розраховані на переконання цієї аудиторії придбати певний продукт. Тому основне завдання перекладача - збереження цієї мети, що вимагає у зв'язку 3 цим урахування певних особливостей і функцій у процесі перекладу.

Економічні процеси, які зараз відбуваються у світі, надали рекламі статусу важливого засобу міжкультурного спілкування. Реклама - важлива сфера діяльності сучасного суспільства. За допомогою таких інструментів міжкультурної комунікації зростає рівень співробітництва між державами в різних галузях, налагоджуються взаємозв'язки між представниками різних культур. Країни мають змогу обмінюватися між собою досвідом на шляху досягнення своїх цілей.

При перекладі текстів реклами потрібно враховувати політичні переваги, демографічну ситуацію, інформацію про стать, расу, релігію, економічні доходи, культурні смаки; уявлення аудиторії про сприятливі можливості та можливий розвиток подій; можливості аудиторії в галузі інформаційних операцій; процеси прийняття рішень $[13$, c. $38-41]$.

Переклад рекламних текстів - це складне завдання, що потребує обов'язкової адаптації тексту до соціокультурних особливостей аудитоpiï. Адаптація РТ - це не лише переклад слів, а й переклад ідей. Лише в цьому випадку реклама буде ефективно виконувати свою роль спілкування виробника зі своєю цільовою аудиторією [11]. 
Завдання на переклад реклами та етапи роботи з РТ можна уніфікувати в такий спосіб:

1. Об'єктно-ідентифікаційні завдання, які складаються 3 дій називання або лаконічного опису зображення, ознайомлення 3 вербальним компонентом і виявлення об'єкта реклами.

2. Змістовно-евристичні завдання, результатом яких $\epsilon$ відкриття імпліцитної соціокультурної інформації, що міститься в РТ. Такі завдання набувають форми проблемно-орієнтованої бесіди або ж проблемних запитань, що передують сприйняттю текстів.

3. Завдання, щчо зумовлені зазвичай невеликим інформативним обсягом окремого РТ i, як наслідок, потребою використання додаткових матеріалів для поглиблення інформованості перекладача, освоєння іншокультурного простору.

4. Завдання, що експлуатують теми, персонажі та зміст РТ для стимуляції продуктивного мовлення та які можна кваліфікувати як ситуативно-стимулятивні.

Сфери спілкування в текстах реклами представлені такими блоками:

1. Торгівельно-комерційна сфера спілкування: реклама банків і банківських послуг, фірм, кредитних карток, послуг супермаркетів, торговельних центрів.

2. Соціально-культурна сфера спілкування: реклама вистав, концертів, фестивалів, музеїв, бібліотек, екскурсій, турпоїздок, подорожей, розваг під час літнього відпочинку, реклама релігійних і національних свят, охорони навколишнього середовища.

3. Навчально-професійна сфера спілкування: реклама різноманітних навчальних центрів i закладів, навчальної та професійної літератури, навчальних предметів.

4. Сімейно-побутова сфера спілкування: реклама харчових і промислових товарів, побутової, аудіо- й відеотехніки, кухонних предметів, ресторанів, кафе, доставки товарів додому, дитячих предметів, літератури, реклама, пов'язана 3 різними сімейними подіями (днями народження, весіллями, ювілеями).

5. Спортивно-оздоровча сфера спілкування: реклама оздоровчих центрів, спортивних комплексів, басейнів, стадіонів, різноманітних лікувальних засобів, реклама боротьби зі СНІДом, палінням, алкоголізмом.

6. Побутова сфера спілкування: реклама готелів, гаражів, перукарень, різноманітних транспортних послуг, поведінки в громадських місцях тощо [5].

При перекладі реклам зазвичай використовують два основні методи: калькування й різного роду перекладацькі трансформачії. Калькування - це відтворення не звукового, а комбіна- торного складу або словосполучення, коли складові частини слова (морфеми) чи фрази (лексеми) перекладаються відповідними елементами в мові іншої країни [14].

При перекладі РТ використовуються такі види перекладу:

1. Наближений переклад, який можна використовувати, якщо дві країни мають схожі реалії. Наприклад, Санта-Клаус і Святий Миколай - різні поняття, але їх можна заміняти один одним у певному контексті. Реклама «Gillette. The best a man can get» - «Gillette. Найкраще для чоловіків» теж належить до наближеного перекладу, адже автору вдалося зберегти риму й сенс, хоча повідомлення не було передано дослівно.

2. Переклад, що виключас використання реалій. Перекладач має враховувати особливості країни та звичні для іiі жителів поняття. Наприклад, «Carlsberg - probably best lager in the world» переклали як «Carlsberg - мабуть, найкраще пиво y світі». Як бачимо, переклад майже дослівний, але, замість слова «лагер», використано «пиво», оскільки в Україні світле пиво ніколи не називають «лагер».

3. Перерозподіл значення без використання еквівалентного слова. Це роблять, щоб максимально зберегти посил тексту, якщо початкова форма не може бути гармонійно перекладена іншою мовою. Прикладом може бути слоган Bounty «A taste of paradise», який відомий нам як «Райська насолода».

4. Дослівний переклад. Влучним прикладом дослівного перекладу реклами вважають слоган M\&M's «Melt in your mouth, not in your hands»«Тане у роті, а не у руках».

Робота над перекладом рекламних текстів вимагає вивчення контексту (переклад рекламних оголошень, статей, слоганів, назв брендів товарів, рекламних листівок і брошур, рекламного ролика, банера, постера тощо), вивчення історії бренду, здійснення перекладу кожного рядка (якщо потрібно), створення кількох творчих і креативних варіантів перекладу, уведення цих варіантів у пошукові системи для перевірки тексту на унікальність, здійснення зворотного перекладу та додавання коментарів.

Найбільш вдалим способом перекладу реклами можна назвати переклад, «близький до адекватного». Цей вид перекладу включає зміну словоформи або взагалі використання інших виразів, що допустимо й широко використовується перекладачами, адже це допомагає домогтися ефективності реклами та передати її посил.

Як відомо, створення яскравого, незабутнього образу - основна мета реклами. На цьому побудовані рекламні кампанії елітних автомобілів, дорогих парфумів тощо. Вони не закликають 
купити, але повинні створити мрію, яскраву картинку, яка надовго запам'ятається аудиторії. Під час роботи з рекламними текстами одним із найскладніших завдань для перекладача стає підтримання й передача цього образу. Для цього він має мислити творчо і креативно. Саме із цією метою перекладачі часто відходять від тексту оригіналу й використовують вирази, які допоможуть добитися того ж ефекту в іншої аудиторії. Професійна робота перекладача дає змогу досягти аналогічного або навіть кращого результату реклами. При сприйнятті рекламного тексту основне - це реакція на образ, який залишиться в пам'яті того, хто сприймає рекламу. Основною метою мови реклами є можливість справити враження, залишити емоційний слід від тексту. Саме образність та імпресивність $є$ основою реклами. Образність також створюється за рахунок семантики слів, того, 3 якими емоціями вони пов'язані.

Без перебільшення можна сказати, що за своєю складністю переклад РТ схожий на переклад художнього твору. Існує лише одна відмінність: художній текст значно більший за розміром. Але це не робить роботу перекладача легшою. Реклама завжди коротка, ємна, містить у собі інформацію, певний емоційний компонент i заклик придбати той чи інший продукт. Тому переклад реклами завжди вимагає від перекладача творчого підходу, який можна втілити за допомогою використання різноманітних художніх засобів і стилістичних фігур.

Аналіз рекламних текстів показує, що в них часто використовуються такі стилістичні фігури: епітети, метафора, порівняння, алегорія, паралелізм, повтори, алітерація, ономатопея тощо. У цих текстах значна концентрація імперативних форм дієслова та конотативних прикметників. При перекладі важливо звертати на них увагу й правильно передавати, щоб не втратити ефективність реклами. 3 упевненістю можна сказати, що найчастіше в РТ зустрічається метафора, переклад якої вимагає від перекладача великого творчого потенціалу. Метафора - це приховане порівняння. Відомо, що людина мислить метафорично, вони огортають наше повсякденне життя [15, с. 235]. Тому в будь-якому дискурсі є складники образності картини світу й елементи поетичної думки. Рекламний дискурс не є винятком.

Метафора - це не лише засіб виразного мовлення, а й дієвий засіб переконання. Метафора вражає своєю унікальністю, допомагає подолати пасивність сприйняття, дуже компактно представляє інформацію, таким чином, сприяє кращому iㅣ запам'ятовуванню та посилює вплив. Дослідники Г. Лакофф та М. Джонсон звернули увагу на найважливіші властивості метафори як засобу мовного впливу багато років тому. У роботі «Мета- фори, якими ми живемо» вони зазначають, що метафори проникають у наші думки та наші дії $[15$, с. 227$]$.

Як відомо, використання метафори в рекламному дискурсі сприяє підвищенню виразності мовлення. Метафора $є$ основною аргументованою фігурою в рекламному тексті. Рекламодавці використовують метафору як інструмент, за допомогою якого можна побудувати композицію реклами, передати їі значення. Візьмемо як приклад рекламу автомобілів: $\breve{S} K O D A$. Simply Clever - ら́KODA. Просто розумний, Confidence in Motion - Bnевненість у pyci (Subaru), Power, Beauty and Soul - Потужність, краса та душа (Aston Martin).

Рекламні тексти також багаті на епітети. Епітет - це слово чи словосполучення, що описує головну якість когось чи чогось. Епітети як визначення дуже важливі в рекламі для візуалізації, оскільки визначення товарів і послуг має викликати специфічні асоціації та образи.

На особливу увагу заслуговують порівняння, які широко використовують у РТ. Дуже часто порівняння використовують 3 метою маніпуляції, оскільки для порівняння застосовують такі параметри, на фоні яких рекламована марка виглядає найбільше виграшно. У рекламі часто можна зустріти слова: «більще», «дешевще», «кращуе», «вигідніше», «єдиний», «унікальний», «супер», «nонад». Усі ці слова $є$ сигналами того, що рекламована марка явно або приховано подається в порівнянні 3 іншими марками тієї ж товарної категорії. Реклама також характеризується гіперболою. Можна сказати, що цей засіб використовується для підсилення властивостей об'єкта, явища, процесу, що не завжди є достовірним.

На морфологічно-синтаксичному рівні найбільш важливими ознаками РТ є часте вживання імперативних форм дієслова, що значно підсилює динамічність рекламного обігу, наприклад: англійські - see, buy, fly; українські - дзвони, заходь, куnуй. В англомовній рекламі поширеними є дієслівні комбінації на кшталт «Buy this», "Discover that», "Try some today», "Don't forget», "Treat yourself». Вони зустрічаються в усіх частинах рекламного тексту - у заголовку, основному рекламному тексті й луна-фразі. Дослідження показують, що співвідношення дієслів в імперативі в українських та англійських рекламних текстах рівне.

Варто також звернути увагу на особливий характер уживання в рекламних текстах особових і присвійних займенників. Рекламна комунікація через людські цінності й норми впливає на формування та зміну світогляду людей і соціальних груп. Тому переконлива тональність рекламного обігу часто будується на послідовному 
застосуванні такої комунікативної моделі: «We, our» - для позначення рекламодавця, «уои, your» - для звертання до потенційного покупця й «they, their» - для посилання на можливих конкурентів. Варто зазначити, що вживання таких форм також характерно й для текстів української реклами.

Загальними рисами всіх рекламних текстів можна вважати специфічний підбір лексики, низькочастотних слів; часто стилістично забарвлені слова; уживання ідіом і цитат для створення образності; заклик до дій за допомогою імперативу; широке використання особових і присвійних займенників; використання номінативних речень; прийом паралелізму та повтору; широкий спектр прикметників і прислівників.

Висновки й перспективи подалыших розробок. Отже, можна зробити висновок, що переклад рекламних текстів вимагає від перекладача знання не лише мов, а й особливостей, традицій і культури країни, їі діалекту, жаргону тощо. Це складний, творчий процес, який потребує врахування багатьох факторів. Передусім треба усвідомлювати, що рекламні тексти повинні сприяти продажу товару або надання послуги, отже, вони повинні бути максимально переконливими і створювати яскраві образи в думках споживачів. Урахування типу рекламованого товару, методу впливу, який використовується при створенні рекламного повідомлення, цільової аудиторії та інших складників дасть змогу створити унікальний та образний продукт, який буде задовольняти вимоги рекламодавців і споживачів. Основні моменти, які треба врахувати, виконуючи переклад реклами: простоту структури, короткі речення, умовність стилю й образність. Для отримання якісного перекладу варто пам'ятати: будь-який текст націлений на те, щоб вразити читача (слухача) за рахунок незвичності мовних зворотів. При перекладі передусім необхідно зосередитися на повідомленні, а не на його формі, ураховуючи культурні аспекти.

\section{ЛІТЕРАТУРА}

1. Авшаров А.Г. Рекламный текст как объект перевода: этнический и лингвокультурный аспекты. Материаль II Международной научной конференции. Москва : Высшая школа перевода МГУ, 2010. 17 с.

2. Бурковська Л. Лінгвістичні аспекти англомовних рекламних текстів. Філологічні науки. 2014. № 18. С. 18-21.

3. Дульянинов А.Г. Рекламные тексты как средство познания культуры. Иностранные языки в школе. 2005. № 4. С. 13-19.

4. Лилова А. Введение в общую теорию перевода. Москва : Высшая школа, 1995. 256 с.

5. Имшинецкая И.А. Креатив в рекламе. Москва : РИП Холдинг, 2002.
6. Медведева Е.В. Рекламная коммуникация. Москва : Эдиториал УРСС, 2003. 232 с.

7. Науменко Л.П. Практичний курс перекладу 3 англійської мови на українську: навчальний посібник. Вінниця : Нова книга, 2011. 138 с.

8. Добросклонская Т.Г. Медиалингвистика: системный подход к изучению языка СМИ. Москва : Флинта. Наука, 2008. 203 с.

9. Goddard A. The Language of Advertising. London, 1998. $133 \mathrm{p}$.

10. Tanaka K. Advertising language: a pragmatic approach to advertisements in Britain and Japan. London and NY, 1994. 38 p.

11. Порческу Г.В. Лингвистические особенности перевода рекламных слоганов и способы их перевода. URL: www.lingvomaster/ru/ (дата звернення: 12.05.2021).

12. English Advertising Language Features and Translation. URL: https://www.academia.edu/ 32890498/ (дата звернення: 23.06.21)

13. Ромат Є. В. Основи реклами : навчальний посібник. Київ : Студцентр, 2008. 288 с.

14. Колшанский Г.В. Контекстная семантика. Серія В. Лингвистическое наследие XX века. 2-е вид. Москва : Высшая школа, 2013. 150 с.

15. Lakoff G., Johnson M. Metaphors We Live By. London : The university of Chicago press, 2003. 267 p.

\section{REFERENCES}

1. Avsharov, A.G. (2010) Advertising text as an object of translation: ethnic and linguistic and cultural aspects [Reklamnyy tekst kak obyekt perevoda: etnicheskiy i lingvokul'turnyy aspekty]. Proceedings of the II International Scientific Conference. Moscow : Higher School of Translation, Moscow State University, 17 p.

2. Burkovskaya, L. (2014) Linguistic aspects of English-language advertising texts [Linhvistychni aspekty anhlomovnykh reklamnykh tekstiv]. Philological sciences. Vol. 18, pp. 18-21.

3. Dulyaninov, A.G. (2005) Advertising texts as a means of cognition of culture [Reklamnyye teksty kak sredstvo poznaniya kultury]. Foreign Languages in School, vol. 4, pp. 13-19.

4. Lilova, A. (1995) Introduction to the general theory of translation [Vvedeniye $\mathrm{v}$ obshchuyu teoriyu perevoda]. Moscow : Higher school, $1995.256 \mathrm{p}$.

5. Imshinetskaya, I.A. (2002) Creation in advertising [Kreativ v reklame]. Moscow : Holding, 2002.

6. Medvedeva, E.V. (2003) Advertising communication [Reklamnaya kommunikatsiya]. Moscow : Editorial URSS, 232 p.

7. Naumenko, L.P. (2011) Practical course of translation from English into Ukrainian: textbook [Praktychnyy kurs perekladu z anhliyskoyi movy 
na ukrayinsku: navch. posib.]. Vinnytsia : Nova knyha, $138 \mathrm{p}$.

8. Dobrosklonskaya, T. G. (2008) Medialinguistics: a systematic approach to the study of media language [Medialingvistika: sistemnyy podkhod $\mathrm{k}$ izucheniyu yazyka SMI]. Moscow : Flint. Science, $203 \mathrm{p}$.

9. Goddard, A. (1998) The Language of Advertising. London, $133 \mathrm{p}$.

10. Tanaka, K. (1994) Advertising language: a pragmatic approach to advertisements in Britain and Japan. London and NY, $38 \mathrm{p}$.

11. Porchescu G. V. Linguistic features of translation of advertising slogans and methods of their translation [Lingvisticheskiye osobennosti perevoda reklamnykh sloganov i sposoby ikh perevoda]. URL: www.lingvomaster / ru / (access date 12.05.21).

12. English_Advertising_Language_Features and Translation. URL: https://www.academia.edu/ 32890498/ (access date 23.06.21).

13. Romat, E.V. (2008) Fundamentals of advertising: textbook [Osnovy reklamy: navch. pos.]. Kyyiv : Studtsentr, $288 \mathrm{p}$.

14. Kolshansky, G. V. (2013) Contextual semantics [Kontekstnaya semantika]. Series B. Linguistic heritage of the twentieth century. Type 2. Moscow : Higher School, 150 p.

15. Lakoff, G. \& Johnson M. (2003) Metaphors We Live By. London : The university of Chicago press, $267 \mathrm{p}$. 